Bulletin of the Natural History Museum, 2019, 12: 209-215.

Received 07 Jul 2019; Accepted 26 Nov 2019.

doi:10.5937/bnhmb1912209T

UDC: 598.125.2(497.11)

Short communication

\title{
NEW RECORDS OF TESTUDO GRAECA (PALLAS, 1814) IN REPUBLIC OF SERBIA
}

\author{
LJILJANA TOMOVIĆ ${ }^{1 *}$, RASTKO AJTIĆ ${ }^{2}$, ANA GOLUBOVIĆ \\ ${ }^{1}$ University of Belgrade, Faculty of Biology, Studentski trg 16, \\ 11000 Belgrade, Serbia, e-mail: lili@bio.bg.ac.rs \\ ${ }^{2}$ Institute for Nature Conservation of Serbia, Dr Ivana Ribara 91, \\ 11070 Belgrade, Serbia
}

The autochthonous distribution range of the Greek tortoise (Testudo graeca) stretches through the Mediterranean and sub-Mediterranean parts of southern Spain, the Balearic Islands, northern Africa (from Morocco to Libya), south-eastern part of the Balkan Peninsula, through Turkey and the Caucasus, and towards the east, through Iran, Syria, Lebanon, Jordan and Israel (Fritz \& Havaš 2007). It occurs from sea level up to $1,300 \mathrm{~m}$ a.s.l. (in Bulgaria), but certain subspecies beyond the European part of the range occupy habitats above 2,500 m a.s.1. (Lambert 1997).

The Greek tortoise in the Republic of Serbia has an extremely narrow and apparently disjunct range. It was recorded in only several localities in south-eastern and southern Serbia, as well as in Kosovo province (Buskirk et al. 2001, Tomović et al. 2004, Ralev et al. 2013, Tomović et al. 2014); its altitudinal distribution ranges from 370 to $600 \mathrm{~m}$ a.s.l. (Tomović 2015). In this paper, we present new field records of Testudo graeca in Serbia.

Until now, this species was only found at the following sites: Starac Mt., village Starac (record no. 11 - Tomović et al. 2004), Preševo Valley, village Miratovac (record no. 12 - Ralev et al. 2013) and Šar Planina Mts., 
village Đeneral Janković (record no. 13 - Tomović et al. 2014); in all locations, only one individual was recorded. The finding from Kosovska Mitrovica (record no. 14 - Buskirk et al. 2001) is questionable because of rational suspicion concerning the origin of individuals deposited in the collection of the Zoologische Staatssammlung Museum, in Munich. Moreover, the Greek tortoise's occurrence in the surroundings of Kosovska Mitrovica was not confirmed during the recent intensive field research of herpetofauna of this region (Tomović et al. 2018).

From 2014 until 2017, comprehensive field research of southern and south-eastern Serbia was conducted in order to provide detailed distribution data for reptile species in the centres of diversity of our country (Tomović et al. 2015). Faunistic studies resulted in 10 new records of Testudo graeca in these regions: two in southern (Preševo Valley) and eight in southeastern Serbia (Starac Mt.) (Table 1, Figs 1-2) with an altitudinal range from 400 to $600 \mathrm{~m}$ a.s.l. (Table 1). Characteristic plant species at these sites are Quercus pubescens, Quercus cerris, Carpinus orientalis and Juniperus oxycedrus (Tomović et al. 2004, Ralev et al. 2013). This is in accordance with general habitat preferences of this species in Serbia: broadleaved deciduous xerophytic forests and scrubs, dry grasslands, woodland fringes and tall forb habitats, fallow land and embankments (Tomović \& Lakušić 2015).

The Greek Tortoise is listed in Annexes II and IV of the Habitats Directive (92/43/EEC), in Appendix II of the Berne convention and in Appendix II of the CITES convention. At the global level, it is considered 'Vulnerable' in the IUCN Red list (Tortoise \& Freshwater Turtle Specialist Group 1996). In the Red Book of Fauna of Serbia II - Reptiles (Tomović et al. 2015), based on both IUCN criteria and upon analyses of distribution, ecology and life-history traits (DELH), Testudo graeca was assessed as Critically Endangered (CR) at a national level. This species is assigned as 'Strictly Protected' by law in Serbia (Anonymous 2010a, 2010b).

According to this updated distribution of the Greek tortoise, we estimated its Extent of Occurrence (EOO - $449 \mathrm{~km}^{2}$ ) and Area of Occupancy $\left(\mathrm{AOO}-10 \mathrm{~km}^{2}\right.$ ) in Serbia, following IUCN criteria (Niketić 2019). Since in all published and new localities, only individual adult specimens were found, we infer that population densities are very low. Additionally, sites where the species was observed are situated at its distribution edge and migrations from the south (North Macedonia) are probably very restricted, giving the fact that tortoises are slow-moving animals. Therefore, regional rescue effects are only remotely possible; this makes Serbian populations of Testudo graeca very fragile in terms of viability. More comprehensive field research is needed to evaluate the accurate population status of this species in Serbia. 
Table 1. - Precise information about published and new field data of Testudo graeca in Republic of Serbia.

\begin{tabular}{|c|c|c|c|c|c|c|c|c|c|c|c|}
\hline No. & Region & Locality 1 & Locality 2 & Toponym & Data & UTM & Latit. & Longit. & Alt. & Sex & Date \\
\hline 1 & Southern & Preševo Valley & v. Miratovac & r. Suva Reka, before the village & field & EM58 & 42.2737 & 21.6497 & 607 & female & $10-05-2014$ \\
\hline 2 & Southern & Preševo Valley & v. Miratovac & near the border line & field & EM57 & 42.2521 & 21.6582 & 588 & female & 01-06-2014 \\
\hline 3 & South-eastern & Starac Mt. & Prohor Pčinjski Monastery & path to Gornji Starac & field & EM78 & 42.3267 & 21.8933 & 523 & male & 28-06-2017 \\
\hline 4 & South-eastern & Starac Mt. & v. Starac & patrol line, path to Čivčije & field & EM78 & 42.311 & 21.8738 & 415 & male & 06-05-2015 \\
\hline 5 & South-eastern & Starac Mt. & v. Starac & patrol line, path to Čivčije & field & EM78 & 42.3128 & 21.8796 & 421 & female & $16-05-2017$ \\
\hline 6 & South-eastern & Starac Mt. & v. Starac & patrol line, path to Čivčije & field & EM78 & 42.3104 & 21.8763 & 404 & female & $17-05-2017$ \\
\hline 7 & South-eastern & Starac Mt. & v. Starac & path Čivčije - Gornji Starac & field & EM78 & 42.3124 & 21.8727 & 466 & female & $24-07-2016$ \\
\hline 8 & South-eastern & Starac Mt. & v. Starac & path Čivčije - Gornji Starac & field & EM78 & 42.3199 & 21.8713 & 606 & female & 26-07-2016 \\
\hline 9 & South-eastern & Starac Mt. & v. Ljanik & near the border line & field & EM68 & 42.3117 & 21.8357 & 477 & female & $26-07-2016$ \\
\hline 10 & South-eastern & Starac Mt. & v. Uzovo & & field & EM68 & 42.3313 & 21.8341 & 550 & female & $26-07-2016$ \\
\hline 11 & South-eastern & Starac Mt. & v. Starac & near Čivčije & literature & EM78 & 42.3157 & 21.8811 & 520 & male & $11-04-2004$ \\
\hline & Southern & Preševo Valley & v. Miratovac & $1 \mathrm{~km} \mathrm{NW}$ & literature & EM58 & 42.2721 & 21.6524 & 550 & male & 13-05-2011 \\
\hline 13 & Kosovo & Šar Planina Mts. & v. Đeneral Janković & & literature & EM26 & 42.1475 & 21.2992 & & & 28-08-1977 \\
\hline 14 & Kosovo & Kosovska Mitrovica & & & literature & DN84 & & & & & \\
\hline
\end{tabular}




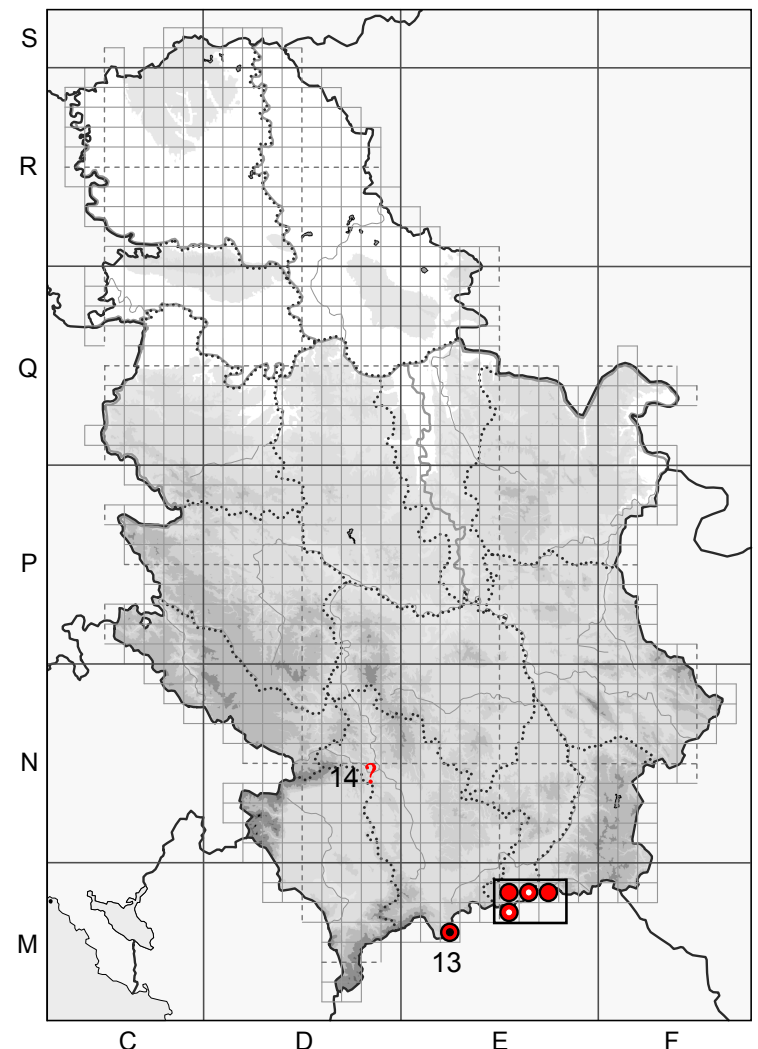

Fig. 1. - Records of Testudo graeca (Pallas, 1814) in Republic of Serbia. Red dots - reconfirmed published data; red-black dots - published data; red-white dots - new data; question mark - doubtful record.

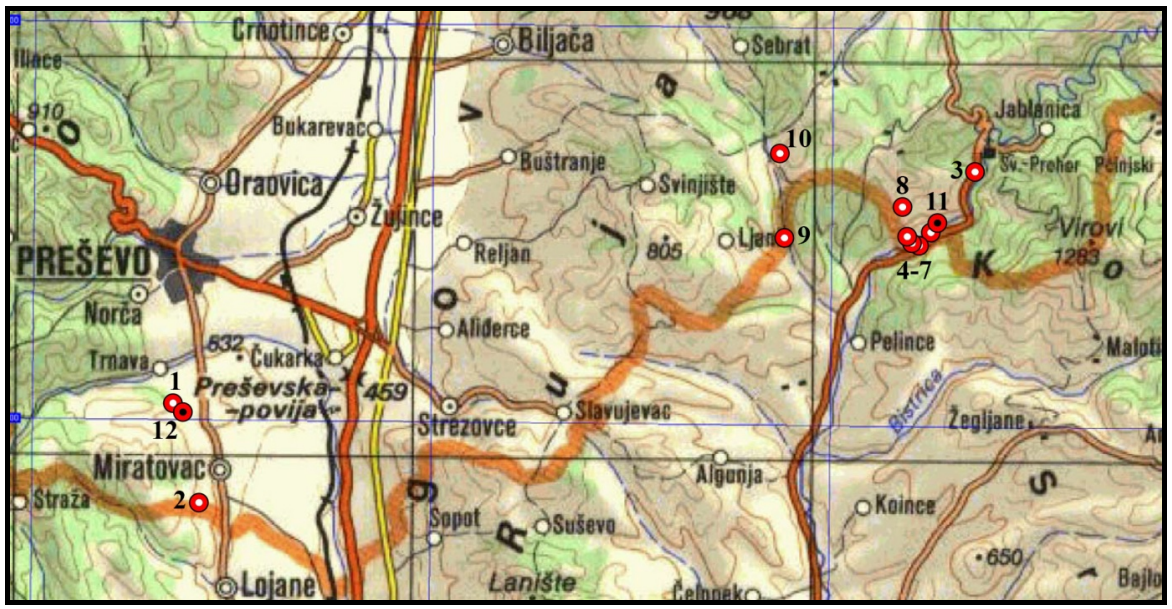

Fig. 2. - Records of Testudo graeca (Pallas, 1814) in the area marked by the rectangle in Figure 1. The dot legend corresponds to Figure 1. 
The southernmost part of Serbia is one of the main refugia and a corridor for reptile species in our country, due to Mediterranean influences via the Pčinja and Moravica River Valleys from the Republic of North Macedonia (Matvejev 1961, Radovanović 1964, Matvejev \& Puncer 1989, Crnobrnja-Isailović \& Aleksić 1999, Tomović et al. 2004, Ralev et al. 2013). The presence of some Mediterranean reptile species in Pčinja River Valley e. g. Podarcis erhardii, Platyceps najadum, Elaphe quatuorlineata (Crnobrnja-Isailović \& Aleksić 1999, Ristić et al. 2006) support the assumption that some species which occur in North Macedonia, could also be found in Pčinja and Moravica River Valleys. Furthermore, the occurrence of some Mediterranean reptiles (e. g. Lacerta trilineata, Zamenis situla, Malpolon insignitus) have been confirmed for North Macedonia relatively close to the borderline with Serbia (Sterijovski et al. 2014 and references therein).

According to analyses of centres of diversity of herpetofauna of Serbia (Tomović et al. 2015 - Figure 4.), Pčinja River Valley, Starac Mt., Rujan Mt., Moravica River Valley (i.e. Preševo Valley) and Karadag Mt. are regions with the highest diversity of reptile fauna in our country. Also, the presence of several Mediterranean species (with probably northernmost populations) is the main argument that these regions should be included in the list of 'Important Herpetological Areas' in Serbia and on the Balkan Peninsula. The occurrence of four species listed in Annex II of the Habitats Directive (Emys orbicularis, Testudo hermanni, Testudo graeca and Elaphe quatuorlineata) nominates the abovementioned regions as priorities for faunistic and conservation studies as part of the future designation of 'Natura 2000' sites in the Republic of Serbia.

\section{Acknowledgments}

We are grateful to J. Pokrajac, V. Bjelica, G. Danon, S. Nikolić, I. Krizmanić, A. Simović, G. Tomović and B. Zlatković for company in the field. M. Niketić provided us the maps of distribution in Serbia. This paper was funded by Ministry of Education, Sciences and Technological Development (grant No. 173043) of Serbia and the Rufford Small Grants Foundation (grant no. 20507-B).

\section{REFERENCES}

Anonymous (2010a): Regulation on proclamation and protection of strictly protected and protected plant, animal and fungi species. - Official Gazette RS 5/10. [in Serbian]

Anonymous (2010b): Regulation on proclamation and protection of strictly protected and protected plant, animal and fungi species. Appendix 1. Strictly protected species. - Official Gazette RS 5/10. [in Serbian] 
Buskirk, J. R., Keller, C., Andreu, A. C. (2001): Testudo graeca Linnaeus, 1758 Maurische landschildkröte. Pp. 125-178. In: Fritz, U. (ed.): Handbuch der Reptilien und Amphibien Europas. Bd. III/A Schildkröten (Testudines) I (Bataguridae, Testudinidae, Emydidae). - Aula-Verlag, Wiesbaden.

Crnobrnja-Isailović, J., Aleksić, I. (1999): First record of Coluber najadum Eichwald (1831) in Serbia. - Archive of Biological Sciences 51: 47P-48P.

Fritz, U., Havaš, P. (2007): Checklist of Chelonians of the World. - Vertebrate Zoology 57: 149-368.

Lambert, M. R. K. (1997): Testudo graeca Linnaeus, 1758. In: Gasc, J. P., Cabela, A., Crnobrnja-Isailović, J., Dolmen, D., Grossenbacher, K., Haffner, P., Lescure, J., Martens, H., Martínez Rica, J. P., Maurin, H., Oliveira, M. E., Sofianidou, T. S., Veith, M., Zuiderwijk, A. (eds): Atlas of amphibians and reptiles in Europe: 176-177. - Societas Europaea Herpetologica and Muséum National d'Histoire Naturelle, Paris.

Matvejev, S. D. (1961): Biogeografija Jugoslavije. - Biološki institut NR Srbije, Monograph. 9, Naučna knjiga, Beograd. [in Serbian with English and Russian summary]

Matvejev, S. D., Puncer, I. J. (1989): Karta bioma, predeli Jugoslavije i njihova zaštita. - Glasnik Prirodnjačkog Muzeja, Posebna izdanja 36: 1-76. [in Serbian with English summary]

Niketić, M. (1999): Software application for the taxon threat estimation. In: Stevanović, V. (ed.): Red Data Book of Flora of Serbia 1. Extinct and critical endangered taxa. - Ministry of Environment of the Republic of Serbia, Faculty of Biology, University of Belgrade, Institute for Nature Conservation of Serbia, Belgrade. [in Serbian with English summary]

Radovanović, M. (1964): Die Verbreitung der Amphibien und Reptilien in Jugoslawien. - Senckenbergiana biologica, Frankfurt a. Main 45: 553-561.

Ralev, A., Popović, M., Ružić, M., Shurulinkov, P., Daskalova, G., CrnobrnjaIsailović, J. (2013): A new record of Testudo graeca ibera Pallas, 1814, in southern Serbia. - Herpetozoa 25: 151-153.

Ristić, N., Tomović, Lj., Ajtić, R., Crnobrnja-Isailović, J. (2006): First record of the four-lined snake Elaphe quatuorlineata (Lacépède, 1789) in Serbia. - Acta Herpetologica 1: 135-139.

Sterijovski, B., Tomović, Lj. \& Ajtić, R. (2014): Contribution to the knowledge of the Reptile fauna and diversity in FYR of Macedonia. - North-Western Journal of Zoology 10: 83-92.

Tomović, Lj., Ajtić, R. (2015): Testudo graeca. In: Tomović, Lj., Kalezić, M., Džukić, G. (eds): Red Book of Fauna of Serbia II. Reptiles: 144-150. University of Belgrade, Faculty of Biology, Institute for Nature Conservation of Serbia, Belgrade.

Tomović, Lj., Lakušić, D. (2015): Habitats of Reptiles in Serbia. In: Tomović, Lj., Kalezić, M., Džukić, G. (eds): Red Book of Fauna of Serbia II. Reptiles: 4963. - University of Belgrade, Faculty of Biology, Institute for Nature Conservation of Serbia, Belgrade. 
Tomović, L., Ajtić, R., Đoković, Đ., Antić, S. (2004): Records of Testudo graeca ibera Pallas, 1814 in Serbia and Montenegro. - Herpetozoa 17: 189-191.

Tomović, L., Ajtić, R., Ljubisavljević, K., Urošević, A., Jović, D., Krizmanić, I., Labus, N., Đorđević, S., Kalezić, M. L., Vukov, T., Džukić, G. (2014): Reptiles in Serbia - Distribution and diversity patterns. - Bulletin of the Natural History Museum, Belgrade 7: 129-158.

Tomović, Lj., Kalezić, M., Džukić, G. (eds) (2015a): Red Book of Fauna of Serbia II. Reptiles. - University of Belgrade, Faculty of Biology, Institute for Nature Conservation of Serbia, Belgrade.

Tomović, Lj., Timotijević, M., Ajtić, R., Krizmanić, I., Labus, N. (2018): Contribution to Herpetofauna of Serbia - distribution of reptiles in Kosovo and Metohija province. - University Thought, Priština 8: 1-6.

Tortoise \& Freshwater Turtle Specialist Group (1996): Testudo graeca. In: IUCN Red List of Threatened Species. Version 2013.2. [http://www.iucnredlist.org]

\title{
НОВИ ПОДАЦИ ЗА TESTUdo GRAECA (PALlas, 1814) У СРБИЈИ
}

\author{
ЉИљАНА ТОМОВИЋ, РАСТКО АЈТИЋ, АНА ГОЛУБОВИЋ
}

\section{Р Е 3 И М Е}

Грчка корњача (Testudo graeca) има веома узак и дисјунктан ареал у Републици Србији. Ова врста је до сада забележена на само неколико локалитета у јужној (планина Карадаг, село Миратовац) и југоисточној Србији (планина Старац, село Старац), као и на Косову (Шар планина, село Ђенерал Јанковић). У овом раду представљени су нови фаунистички налази грчке корњаче у нашој земљи. У периоду од 2014. до 2017. године, интензивна истраживања херпетофауне у регионима јужне и југоисточне Србије, резултирала су открићем 10 нових локалитета на којима је присутна врста Testudo graeca. У Црвеној књизи фауне Србије II - гмизавци, грчка корњача је категоризована као критично угрожена врста (Critically Endangered - CR) на територији Србије. Иако је конзервациони статус ове врсте дефинисан, додатна теренска истраживања су неопходна како би се одредио популациони статус ове врсте, која се иначе налази Анексима II и IV Директиве о стаништима (Habitats Directive, 92/43/EEC). 